\title{
The world situation and the main lessons of 30 years of fight against the red palm weevil
}

\author{
Michel Ferry \\ Phoenix Research Station, Aspe, Spain, email: ferry.palm@gmail.com
}

\begin{abstract}
Ferry, M. 2019. The world situation and the main lessons of 30 years of fight against the red palm weevil. Arab Journal of Plant Protection, 37(2): 109-118.

For the last 30 years, imports and movements inside the countries of infested palms have led to the introduction and the spread of the RPW in all the countries of the NENA region (expected Algeria and Sudan) and in all the countries of the Northern Mediterranean coast. Most of these imports and movements have been officially authorized. In the Mediterranean region, hundreds of thousands of ornamental palms were imported from Egypt between 2000 and 2007. In all the infested countries the programmes to control this pest failed and the present situation is presently very serious with important socio-economic impacts in date producing countries and major landscape damages in places where palms were planted for ornamental purpose. To propose valid and sustainable solutions to control this dreadful pest, it is essential to draw lessons from this widespread failure and from the few cases where the control of this pest was successful. These main lessons are: imports and movement of palms must be forbidden when the shoots measure more than few cm diameter; containment strategy fails if it is not associated with efficient programmes implemented to obtain rapid RPW decline; eradication conceived as a long term objective represents a strategic mistake; with the existing tools, eradication is possible; the paradigm that pest eradication means automatically infested palms eradication is wrong; the main problem is not technical but socio-economic and organizational; socio-economic studies must be urgently realized and participatory approach methods must be implemented to involve the palms owners and their organizations at a large scale in the RPW rapid decline and eradication programmes.

Keywords: Rhynchophorus ferrugineus, Phoenix dactylifera, Phoenix canariensis, ornamental palms market, eradication, rapid decline, containment, NENA region, Mediterranean region, socio-economy, phytosanitary regulation, sanitation, management, participatory approach, IPM, GIS.
\end{abstract}

\section{Introduction}

The origin of the world RPW spread (Fig. 1) is anthropogenic, not accidental and, in general, not due to illegal introduction of palms. RPW was introduced from infested country to other countries with infested imported palms.

The importation of palms responds to two different demands: the demand for selected seedlings for coconut or dates production; the demand for ornamental palms that has increased a lot over the last 20 years because palms have become worldwide fashionable landscape trees.

In the infested countries, RPW spreading is also mainly due to movement of infested palms. Indeed, its dispersal behavior is aggregative (Faleiro et al., 2002; Massoud et al., 2012). It is very sensitive to the dryness of the air (Aldryhim and Khalil, 2003; Monzer and Hesham, 2009), a factor that limits to very short distances its own capacity of displacement in the dry regions.

Furthermore, the flying behavior of the RPW corresponds to movements that are not straight, except for short distances; it is used to do laps (Personal observations). Therefore, the results obtained with flight mills (Hoddle et al., 2015) must be taken with precaution before extrapolating them to field conditions. Consequently also, expressions like "RPW has spread", "it has expanded", etc should be replaced by RPW has been spread, expanded, dispersed, etc. For the same reasons, calculating the RPW displacement per year based on the distance between countries or oasis where the RPW is successively detected, does not have much sense.

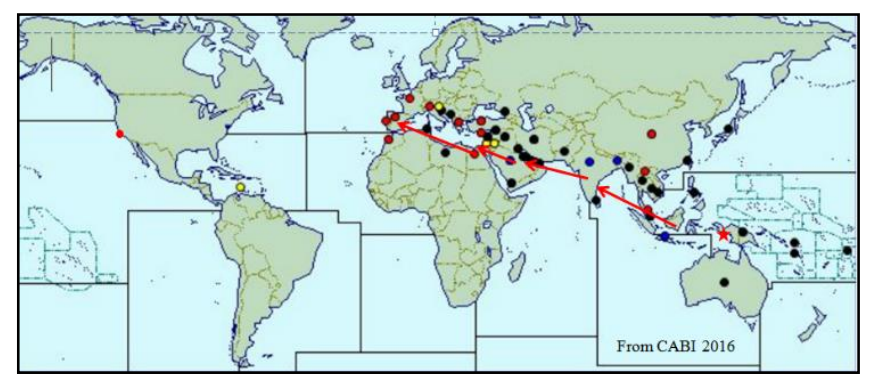

Figure 1. A map showing the world spread of the red palm weevil, due to infested palms exchanges.

The zone of origin of the RPW is South-East Asia. It has been reported in India around 1900 where it has become mainly a coconut pest. Nearly a century later, it was introduced in various places of Eastern region of the Arabian Peninsula and is now present in all the countries of this region, where it has become the main pest of the date palm. It was introduced in 1992 in Egypt, and in 1999 was discovered in Israel and Jordan. It was also introduced in a small area in Spain in 1992. From this last location, contrary to what is sometimes written, it did not spread, naturally or through infested palms exchanges, to the rest of Spain. The explosion of the RPW in Spain as well as in the other Mediterranean countries is linked to an intense trade of 
palms imported from Egypt and from ornamental palms of the nurseries that were infested through these imported palms. In less than 10 years, all the Mediterranean countries, except Algeria, were infested.

RPW is a rapid palm killer. When a palm is infested, if nothing is done to sanitize it, it will be killed inevitably (natural recovering are exceptional) and rapidly, regardless of its size.

Consequently, it is the cause of the death of a very large number of date palms in Egypt and in the Middle East with serious economic consequences, although economic studies are nearly totally missing to assess precisely the dimension of the problem.

In the Mediterranean region, except in Egypt, Jordan and Libya where it is affecting date palms (In Israel, it is affecting now Phoenix canariensis and date palms), the main consequences of its presence is the hecatomb, in less than 15 years, of probably around one million of Phoenix canariensis planted in the cities, a great part of them of large size and exceptional patrimonial value. This species has constituted nearly $100 \%$ of the palms that have been killed by the RPW (without considering the smaller palms killed in the nurseries). The specific hecatomb of Phoenix canariensis is due to two reasons: (1) this palm specie has been planted abundantly in all the Mediterranean cities during the last two centuries; (2) RPW has high preference for $P$. canariensis as compared to date palm of more than 2-3 meters (rarely attacked), or Washingtonia robusta and other different small palm species that are also abundant in the cities.

For more than thirty years, programmes have been implemented to control this pest. For more than 20 years, the strategy and the techniques to eradicate this pest on date palm have been established (Abraham et al., 1998) and confirmed (Faleiro, 2006). On Phoenix canariensis, the strategy and techniques to eradicate this pest was established in 2007 and 2008 (Ferry and Gómez, 2007a; Ferry and Gómez, 2008). In the few cases where these strategy and techniques were implemented, they perfectly demonstrated their efficiency to eradicate the RPW.

Taking into consideration the seriousness of the situation, it is urgent to draw lessons, from this long experience to control or to eradicate the RPW, to identify the mistakes that were made and to propose solutions to solve them.

\section{The Situation in the Northern and Eastern Mediterranean Countries}

As already indicated, all the countries of the region are heavily infested, with the pest, present in nearly all the places where Phoenix canariensis is present. The hecatomb of palms of this species has been very rapid and considerable because of inappropriate regulations and technical measures (Ferry and Gómez 2007b; Ferry and Gómez, 2013), weak or absent management at the national, regional and local levels, and lack of organization to implement collective action plans, conceived to obtain the quick decline of the pest population.

Only in one place, the Canary Islands, where the RPW was infested Phoenix canariensis in the cities, the pest was eradicated rapidly (7 years) and therefore, fortunately, never reached the wild Phoenix canariensis forests (Fajardo, 2017a).

The failure has been so important in the European countries that in 2017 the European Commission decided not to register the RPW in the quarantine pest list except in United Kingdom, Ireland, Azores (CE, 2017).

The case of Israel is different, but the outcome is now more or less similar. In Israel, where the first RPW outbreaks were perfectly eradicated between 1999 and 2002, a new outbreak on Phoenix canariensis in the northernmost city of the country was discovered in 2009. Unfortunately, the management of this new outbreak followed the disastrous pattern similar to the one adopted in Europe. Consequently, RPW has reached the date palms plantations since 2013 (personal observation) and it is now widespread in most of the country.

\section{Present Situation in the Near East and North Africa Region}

Quantitative Data on pest status are generally absent. Therefore, the analysis for each country will be essentially qualitative.

\section{Mauritania}

Official notification was made in December 2015. The pest was introduced in only one oasis (Tidjikja) with infested offshoots imported in a container from the U.A.E., as a consequence of an unsatisfactory respect of the regulations.

Eradication is under way. No captures were observed in traps and no new infested palms were detected since April 2017 (N. Nasr, personal communication).

This promising result can be attributed to various reasons:

- The FAO North Africa Project from 2012 to 2013 during which technicians for the PPOs of each North Africa countries, including Mauritania, were sensitized on the seriousness of this pest and trained on the different components for RPW control (Ferry 2012a, Ferry 2012b).

- Very quick reaction of the PPO in Mauritania when infested palms were discovered and rapid elaboration and implementation of FAO/Ministry of agriculture urgency project for the eradication of the RPW, with rapid supply of the products and equipments necessary to implement the different components of the eradication strategy.

- Immediate and constant mobilization of the Government at the highest level.

- Strong early involvement of Tidjikja palms owners. This fact to a great extent explains the results obtained.

- Various missions of FAO RPW experts to assess the situation and the activities and to train the staff of the Ministry of Agriculture and the farmers (Faleiro et al., 2017).

\section{Morocco}

Official notification was made in December 2008. Possible introduction via RPW adults accidentally transported by 
vehicles and boats from Spain to Tangier or via small ornamental palms introduced from Spain.

Reinforcement of the legislation that prohibits now totally any importation of palms of more than $6 \mathrm{~cm}$ diameter.

Detection of the pest until 2016 only occurred in the city of Tangier, where it has affected only the ornamental Phoenix canariensis, especially the tall ones. Important means were immediately devoted to the eradication project. All the activities were under the control of PPOs. Very quick organisation of a training of the national team by an expert from the Phoenix research station was implemented (July 2009), followed by the reinforcement of the training through the North Africa FAO Project for the control of the RPW.

Results in Tangier: RPW has been contained in the city of Tangier. In the infested sector, the number of new yearly infested palms fluctuates now around 50.

New outbreak in Nador was discovered in 2016. Probably because of the natural dispersion of RPW coming from infested palms in the neighbor city of Melilla where the RPW has not been eradicated (in contrast with Ceuta where no new infested palms have been detected for the last 3 years). The number of infested palms detected in 2016 and 2017 was relatively important as they represented $8 \%$ of the total number of palms (El Iraqui, personal communication, 2018).

\section{Algeria}

Not present. Reinforcement of the regulation (palms imports totally prohibited) and of the control at the borders. Awareness campaigns in the whole country and especially in the oasis are launched.

\section{Tunisia}

Official notification was made on December 2011. Introduced from ornamental palms imported illegally from Italy.

First detected infested palms were in Cartage (North of Tunis) on Phoenix canariensis. Now RPW is spread in most of the cities of the Great Tunis, but it has been also detected in Bizerte and Hammamet.

All the activities were under the supervision of the Ministry of Agriculture.

The containment in its original sector of infestation failed. As demonstrated by the worldwide experience, when RPW is not sufficiently well controlled in the infested areas to obtain its rapid decline, its containment is doomed to fail. Among other aspects, the actual presence in the infested areas of Tunisia of numerous infested palms that are abandoned or sanitized (or eradicated) too late makes impossible to obtain such decline and, consequently, to avoid the further accidental dispersal of the RPW.

The plan of action proposed by FAO in 2012 (Ferry, 2012c) was implemented in its totality and efficiently by a team of the Ministry of Agriculture exclusively dedicated to this plan during the first semester of 2014: communications, location of all the palms, frequent inspection of the palms for early detection, immediate sanitation of the infested palms or eradication of the infested parts (palm head feeling and eradication), mass trapping, preventive treatments (Head felling and eradication of infested palms constitute a provisional measure to eradicate more rapidly the RPW present in an infested palm. Nevertheless, the remaining trunk, even if it is not anymore a potential host of the RPW, has to be to cut later, because it presents a risk to fall down in the future).

Because RPW decline has not obtained and, especially, because of the presence of infested palms that are not sanitized or eradicated sufficiently rapidly, the risk of an accidental introduction of RPW in the oasis is now very high.

\section{Libya}

The RPW was first detected in Tobruk in January 2009, and was detected a bit later in Tripoli. Little information is available regarding this country. It is supposed that the pest was introduced in Tobruk from date palms coming from Egypt, and in Tripoli from ornamental palms coming from Tunisia. From the first infested palms in Tripoli, the pest has spread to the farms around this city.

The implementation of the plan of action to eradicate the RPW proposed by FAO in 2012 could not be initiated. Nevertheless, technicians of the Libyan PPO have at least benefited of the training organized in Tunisia and the study tour organized in Oman in 2012 by FAO.

There is a preoccupation in Tunisia that the possible import of offshoots of one reputed Libyan variety could introduce the pest in the Tunisian oasis that are close to the border.

\section{Egypt}

The RPW was detected in Egypt in 1992. It was introduced from offshoots imported from Saudi Arabia or the UAE. It was detected initially in two small places in the Governorates of Sharquiya and Ismailia (Cox, 1993).

Eight years later, more than 200000 infested palms were detected in 13 different governorates (El-Sebay, 2007). Figure 2 (El-Sebay, personal communication, 2007) shows the locations where the RPW was introduced from 1992 to 2000 .

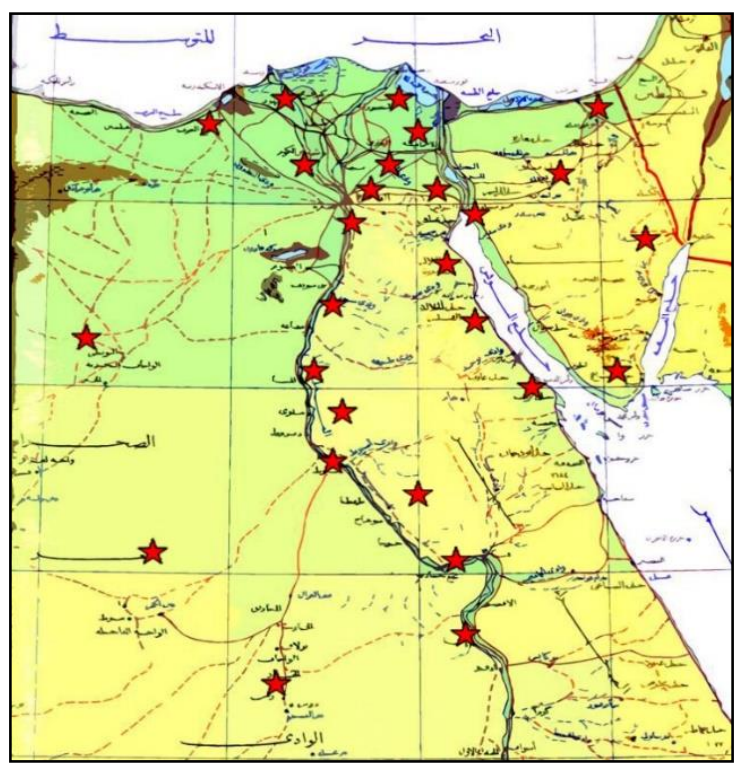

Figure 2. Spread of red palm weevil in 2000 (El-Sebay, 2007). 
The quick dispersion of RPW in the whole country was not the result of the natural RPW spread between oasis. It was due to the movements of infested date palms for ornamental use and of infested offshoots from tissue culture palms (2006 personal observation in new planted area in Egypt) as well probably of new offshoots imports.

The RPW control programme is now principally in the hands of the farmers, who, because of insufficient training and lack of extension agents, lack of sufficient knowledge on the pest and on the way to control it. The number of infested farms and infested palms in the farms is increasing. This situation is made worse in places with new plantations as young date palms are much more susceptible to RPW than palms without offshoots or with trunk of more than 2-3 m high (In higher and older palms, tissues of the petioles bases along the trunk are dead or too dry for successful oviposition) (Ferry, 2017).

\section{Sudan}

RPW is not present, but there is a high risk of introduction as palms importation is not totally prohibited and establishment of new large date palms plantations is planned.

\section{Jordan}

The RPW was detected in Jordan on date palms in 1999 in a plantation located in the Jordan Valley at Shuna, not very far from one of the infested sites discovered in Israel during the same year. The programme to control the RPW was implemented by the Ministry of Agriculture. RPW was successfully contained in the small area where it was initially found and it was considered eradicated or at least very residual in 2005 (Dr. Mona Mashal, personal communication, 2018).

Another outbreak very far from the first one was discovered in 2013 in Azraq. The infested area is much more important. More than 400 date palms were eradicated in 2016.

\section{Palestinian territories}

West bank - In this part of the territory, palms are essentially ornamental. RPW from the infested Phoenix canariensis present in growing number in Israel, including in Jerusalem, are also infesting the Phoenix canariensis of the West Bank.

Jericho - RPW was only captured in traps. As the plantations are still young, risk of infestation is high (Ferry, 2014).

Gaza - RPW discovered for the first time in September 2011 in a nursery of the central zone of Gaza strip. RPW is now spread in the whole strip with a high rate of infested palms. The combined high number of weevils and of young palms leads to a very explosive situation.

Control programme is under the management of the Ministry of Agriculture, but with an exceptional and efficient participation of the farmers, and the assistance of various associations and the support of FAO.

As infested palms are present in the Egyptian sector of El-Arich, bordering the southern part of Gaza strip, a programme to obtain the rapid decline of the RPW in the Gaza strip would require the establishment of a buffer zone along the border (Ferry, 2014). New threat exists now from the North as ornamental Phoenix canariensis are present in the southwestern part of Israel.

\section{Saudi Arabia}

RPW was discovered for the first time in 1987 in Katif. It is considered that it was introduced with ornamental palms.

It is now present in the majority of oasis (Fig. 3). The present situation is the result of the introduction of new infested palms from abroad and of infested offshoots dispersal, especially from tissue culture palms.

The high number of weevils and the high number of young palms lead to a very explosive situation especially in Qasim and Al Kharj provinces. In Al-Ahsa, thanks to important efforts that have been dedicated for a long time to control the pest, the situation is stabilized but the percentage of infested farms is very high (Ferry et al., 2016).

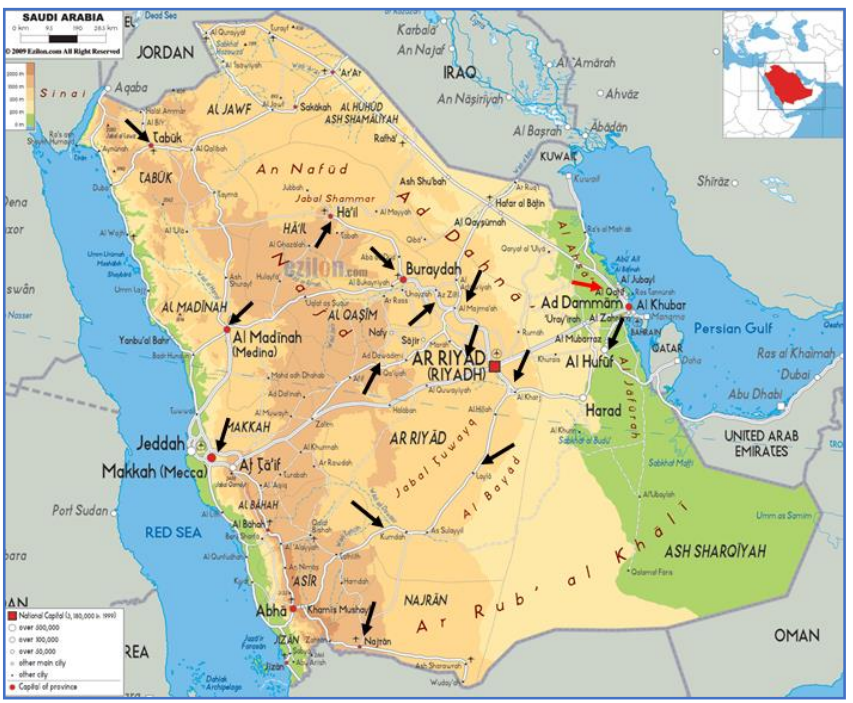

Figure 3. Spread of the red palm weevil in the oasis of Saudi Arabia. The red arrow points to the first discovered spot of Katif.

In KSA, the activities of RPW control programmes are mainly implemented by the Ministry of Agriculture regional authorities. Farmers are little involved, except at the level of some new large farms.

This model of management has not allowed to obtain the eradication of the RPW or even its continuous decline. Very huge resources and budget have been dedicated for numerous years, more than 20 years in Al-Ahsa, to such programmes. They correspond to a scenario that is unsustainable for economic and environment reasons (Ferry et al., in press).

In the framework of the New Saudi Vision 2030 regarding the agriculture sector, new management programmes based on implementing methods and activities to involve much more the farmers have been proposed (Abdedaiem et al., 2017; Ferry et al., 2016). 


\section{Oman}

The pest was discovered for the first time in august 1993 in the province of Mahda, close to the infested oasis of Al Ain in the UAE.

It is now present in most of the provinces where date palms are grown.

A task force established by the Ministry of Agriculture has been created to intervene immediately when new infested palms are notified by the farmers. Huge and efficient efforts to inform the people and make them aware of the seriousness of the pest and of the risk presented by the transport of palms have been developed.

Thanks to this policy, the eradication of the RPW has been successful in many provinces. Unfortunately, because of the introduction of new infested palms, several of these places have been re-infested (Ferry, 2012d).

With the one million date palms project, the challenge to prevent re-infestation becomes still more urgent as the young palms are much more susceptible to the pest than the older palms.

\section{United Arab Emirates}

It was the first gulf country where RPW was detected in 1985. It is now present in nearly all the oasis and the situation is very critical because millions of palms were planted during the last 30 years. The presence of offshoots and the size of these palms are very favorable to RPW infestation.

Except for some big farms, the RPW control programme is under the entire management of the authorities or of contracted companies.

\section{Qatar, Bahrain, Kuwait, Yemen}

The pest was detected in late 80's in Kuwait, in 1989 in Qatar, in 1993 in Bahrain and in 2013 in Yemen.

Until now, no decline of the pest has been obtained in these countries, and the problem is getting worse because new date palms plantations have been established during the last 20 years. No more data available.

\section{Iraq}

The pest was detected in October 2015 in Safwan (Basrah region) very close to the border with Kuwait.

Eradication program is going on. As the infested area is still small, quick eradication is perfectly feasible. But, the proximity with infested date palms plantations in Kuwait should lead to the implementation of a regional eradication project.

FAO organized a training of trainers programme in Irak on March 2017. Considering the efficient work that was realized in Safwan since the date of the RPW detection, the on-going programme could perfectly become a success story if strong coordination is implemented with the progamme in Qatar and if FAO could maintain a technical assistance.

In Iraq, new date palms plantations programmes are carried out or planned for the near future. Reinforcement of the regulation (Prohibition of date palm imports), reinforcement of the control at the borders and improved awareness of farmers and other stakeholders should be realized.
Iran

The Pest was detected in Saravan county in 1990, in Nik Shahr and Fanuj in 2012, in Homozgan and Bushehr provinces in 2014, and new detection in Fars province in 2017. The three last detections were linked with the importation of offshoots from Qatar and U.A.E.

No RPW decline was obtained in the oldest infested areas. New infested regions emerged due to inadequate or not rigorously implemented regulations.

\section{Lessons learned}

Lesson 1: It is impossible to eradicate this pest if the regulations are not adapted or not applied to avoid imports or within country movements of infested palms This lesson is evident, nevertheless, in most of the infested countries, the importation of infested palms or the movement of infested palms inside the countries were done in a perfectly regulatory way, in accordance with the quarantine regulations of the countries. These palms were introduced with official phytosanitary certificates and after an official inspection procedure. In the countries where phytosanitary passport were enforced to move the palms, the infested palms were moved and traded with their passport.

Of course, they were imported or moved inside the countries without knowing that they were infested. But, the Phytosanitary Authorities were aware that the palms allowed to be imported or moved were coming from infested countries or regions, and sometimes from very infested places. Unfortunately, they trusted the value of the phytosanitary certificate or they considered that it was possible to inspect efficiently the palms. These views constitute very serious mistakes because it is impossible to detect the eggs or the small larvae that are hidden in the tissue of the palm, so the implementation of an inspection to establish a phytosanitary certificate or to control a palm at the border has no value (Ferry and Gómez, 2002).

In most of the countries, the banning regulation for palms imports or in country movements, when it was taken, was taken very late when the RPW had been already largely spread. Furthermore, in many countries (e.g. in Europe), the quarantine regulations were inapplicable or inefficient to avoid the importation or the movement of infested palms (Ferry and Gómez, 2002; 2013). These regulations were often wrongly elaborated because the phytosanitary authorities tried to avoid a rigorous ban for fear to hamper the import traders and the nursery sector activities.

The ban of importation is not too difficult to be implemented because huge ornamental palms, palms in pots (small palms in pots don't present risk) or batch of offshoots are usually easy to detect at the border. It is thanks to this ban that Algeria is still free of the pest. Unfortunately, in some countries where importation was totally banned (e.g. Tunisia), the RPW was introduced because the regulations were not respected due to the intervention of VIPs.

Another aspect that explains, to a large extent, the failure of regulations respect inside the country is the lack of information. People who need palms seedlings (farmers, landscapers, etc.) ignored generally, and still often ignore, the risk presented by the RPW. They are also totally confident because the provider assures them that the palms 
are free of the pest as indicated in the phytosanitary certificate or the phytosanitary passport.

Furthermore, the authorities are very often very reluctant to communicate on the presence and the spread of a quarantine pest. Many countries in Europe as in other regions, had, and still have, the tendency to hide this information at the international and also at the local level for various reasons, including political and economic ones. Among many other cases, the information blackout on the RPW problem in Egypt between 1993 and 2000 (Ferry, 1996; Ferry and Gómez, 2002) contributed to the quick spread of the pest in Egypt but also to avoid a palms import ban in the European countries to which hundreds of thousands palms were exported from 2000 to 2007.

The consequences of such behavior are dramatic. Palms owners and palms sector are maintained in the ignorance of the situation instead of being alert and being in position to act to save their palms and to prevent the spread of the pest.

The palms owners are also, sometimes, reluctant to declare that they have found an infested palm for the consequences that can come out of such declaration. To obtain their collaboration in this field and, in the case of the farmers, to obtain a better respect of the ban, it is indispensable to explain to them the challenge of an eradication programme and to implement participatory methods that will facilitate their adhesion to such programme (see lesson 4).

\section{Lesson 2: containment fails if eradication programmes fails}

In all the infested countries, RPW containment failed. It failed because to prevent RPW spread outside the infested zones, it is necessary to obtain the quick decline of the pest in these zones and then its eradication.

If, in the infested zones, strong programmes to obtain the rapid decline of the RPW population are not implemented, its population will grow and RPW will look for palms outside the infested zones. A buffer zone will constitute a barrier to prevent its natural spread only if palms are not present in this zone. Otherwise, even if the palms are scattered in this zone and beyond, as the RPW has the capacity to find palms located at some kilometers away from the palm that it has abandoned (personal observation in Elche), its spread will not be stopped if, at enough short distance, there is relay palms where it will breed.

In addition to this natural spreading, must be added the accidental spread that has probably played a more important role than usually consider in RPW dispersal: its accidental transport in vehicles. It is well established, for example, that RPW can move with persons that have handled RPW pheromone diffusers or have been in contact with infested palms. This is why regarding the RPW pheromone handling, it is strongly advised to move the diffusers including the empty ones in closed containers. Transport of fresh cut palm leaves can also contribute to the displacement of RPW which is attracted by the leaf wound smell and will hide between the leaves. Of course, it is also well established that RPW will be very attracted to felled infested palms or portions of infested palms. The transport of such wastes, often to reach a facility that has been created to shred these wastes, has contributed to its dispersal far beyond its natural spreading capacity. It is now strongly recommended to handle all these wastes on the spot (Ferry and Aldobai, in press).

Nevertheless, the main reason of the containment failure has been certainly the transport of palms and offshoots from infested areas to non-infested ones. For all these reasons, it is essential to implement programmes aimed to obtain quickly the decline of RPW to succeed in its containment.

Lesson 3: RPW control programmes based on suppression or on long term eradication objectives are unsustainable.

Figure 4 shows a schematic representation of three different simplified scenarios of RPW control programmes implemented worldwide.

In some places, RPW control programmes have led to the losing race scenario (Fig. 4, left). For these countries, there are two options that represent both a difficult decision:

- $\quad$ either to stop the programmes. In the losing race scenario, an increase of the efforts is figured from year 5. Such increase is useless as it is not sufficient to prevent the exponential growth of the RPW.

- or, if the majority of the main stakeholders are convinced of the interest to save the palms, to conceive them on quite different bases, including especially measures to involve much more the palms owners and their organisations.

In a small group of countries or in some oasis, RPW control programmes have been carried on for many years without obtaining the continuous RPW decline (Fig. 4, center).

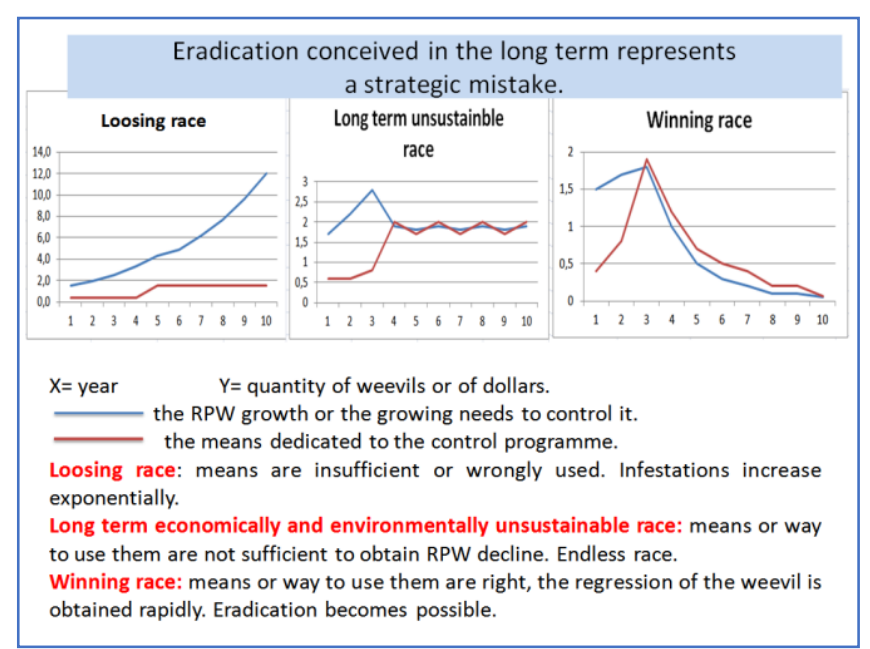

Figure 4. Schematic representation of three different simplified scenarios for RPW control programmes implemented around the world.

These programmes are doomed to fail because they are costly and require permanent activities and vigilance, they don't prevent the progressive loss of palms and RPW spread and they are unsustainable because of the frequent use of insecticides. The two options presented for the previous scenario must be considered. The winning scenario is shown in Figure 4, right. 
The rapid decline of the RPW is obtained in few years and then its eradication became quite possible. It is exactly what has been obtained in various oasis in the Middle East (especially in Oman), in Canary Islands or Ceuta in Spain and in Israel (temporally). The success of the corresponding RPW control programmes was mainly based on right organization and management of the programmes, with active participation of the palm owners. When such programmes have to be implemented on large scale, the approach must be to reallocate the means and the activities progressively from the zones where the RPW has been eradicated to the neighboring zones.

An area-wide eradication programme requires for its success to apply participatory methods aimed to mobilize the first concerned stakeholders, the palms owners and their organizations. It requests also a selection of methods affordable and appropriable by the palms owners or their workers themselves, after training farmers trainers or extension agents. All or most of the methods of the IPM strategy that have been applied in the successful programmes to eradicate the RPW can be easily transmitted to the farmers and their workers and applied by them. In a very infested area in South-East France, an eradication programme based on these principles was initiated in 2016. The first results are very promising with a notable decline of the number of new infested palms.

Some entomologists will probably considerer that the success of such programmes is unrealistic. I think that this opinion is due first to a wrong conception of the difficulties. They are not especially linked to the biology of the insect but much more to socio-economic constraints which analysis and methods to overcome them escape generally, and this normal, to the expertise of entomologists. Secondly, the information on the high percentage of success of the eradication programmes is not known as it should be. So, exists often an a priori against the possibility to eradicate a pest. However the percentage of success of the eradication programmes against pests is high. For example, it has been of $76 \%$ in the USA for the last 50 years against pests in urban environment, where however such programmes are especially complex to manage (Kean et al., 2019).

Lesson 4: without multidisciplinary and participative approach, eradication programmes are doomed to fail

In the RPW control programs, the role of the palm owners and of their organisations has been dramatically neglected, whereas in fact it is fundamental. A lot of knowledge has been accumulated on the RPW and on the relations between palms and this pest, but very little qualitative and quantitative information is available on the economic consequences of the pest for the palm owners (Figure 5).

Most of the scientists and technicians that have published or are involved in the programmes to control the RPW have been entomologists or plant protection technicians. The number of papers published, even on the economic impact of the RPW at the local or national level, are extremely rare. A much better knowledge on the socioeconomic component of the problem is absolutely and urgently indispensable.

As indicated in lesson 3, the involvement of the palm owners and their organizations is a key issue to success of
RPW eradication, especially on large scale. Socio-economic experts capable to establish the typology of the different farming systems in relation with the RPW problem and to implement participatory approaches must be part of the RPW control programmes teams.

The failure of the RPW control programmes is not due to the inefficiency of the techniques to control this pest as demonstrated by the projects that have succeeded to eradicate it. The main problem is the extreme high difficulty to apply at a large scale these techniques without the involvement of palm owners and their organizations. If they are involved because socio-economic expertise, efforts and methods are dedicated to this purpose, the panorama becomes totally different.

It is also thanks to such involvement of the palms owners that new technologies adapted to their needs and capacities, which could differ according to the different farming systems, could be usefully developed because conceived with them.

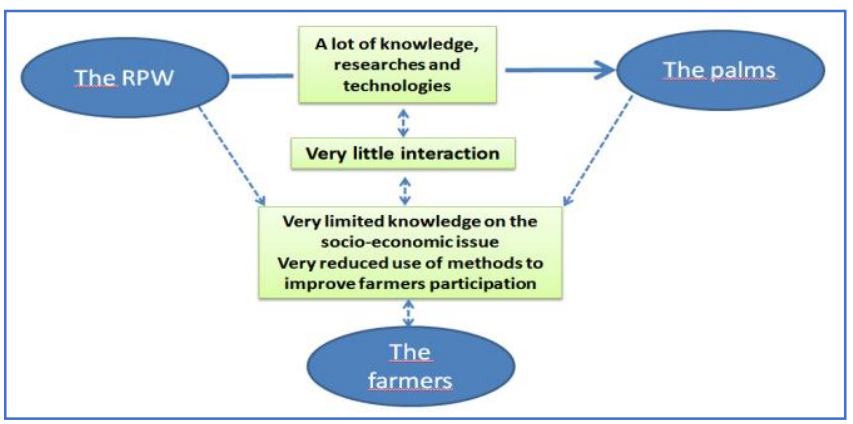

Figure 5. Asymmetric knowledge on the global problem

Lesson 5: eradication of the RPW should not mean automatically the eradication of the infested palms and still less the eradication of the whole infested palms

In the fight against a quarantine organism, eradication of the infested host constitutes a paradigm that is rarely questioned by the phytosanitary authorities. It is usually the first phytosanitary measure adopted, completed often by the eradication also of the non-infested pest host close to the infested one. When alternatives to host eradication exist, this paradigm should be seriously reconsidered, not only because it can be counterproductive, but also because the eradication of the pest's host could lead the pest to spread farther, looking for new hosts.

In the case of the RPW and the date palm, although mechanical or chemical sanitation of infested palms was practiced for a long time, the eradication of the whole infested palms was proposed as the best solution to eradicate the RPW. It was even compulsory, and in some countries it is still the case. Regarding the Phoenix canariensis of more than 2-3 m height that are generally infested at the bases of the higher leaves, mechanical sanitation was also developed (Ferry and Gómez, 2008). Nevertheless, two to four years were necessary to obtain the authorization of this technique in Europe. Previously, in all the European countries, it was obliged to systematically eradicate the whole infested palms.

For date palm as well as for Phoenix canariensis, this recommendation or obligation to eradicate the whole palm 
was based on generalized misconception on some important aspects of the RPW biology.

First, it was considered that when a palm was infested, RPW in all its forms and especially the larvae could be present in any part of the palm and accordingly it was preferable to eradicate the whole palm (as if it was contaminated by a microorganism!). This is totally wrong, because in an infested palm, it is very easy and safe to delimitate the parts were the RPW are present, and that usually represent a very small portion of the palms, especially in the large palms or when infestation has been detected early. The eradication of these infested parts is quite sufficient (Ferry and Gómez, 2008; Ferry and Aldobai, in press).

Usually, for date palm, these infested parts are offshoots or portions of the trunk and sometimes bases of the leaves. For Phoenix canariensis of less than 2-3 m height, the situation is similar, except of course that they don't have offshoots. For higher Phoenix canariensis, the infested parts are the basis of the leaves (except usually the leaves of lower crown) and small portion of the upper part of the trunk.

Secondly, it was considered - and in many places it is still the case - that the wastes after a mechanical sanitation (remaining trunk, leaves) will constitute egg laying sites. It was also considered, that if eggs or larvae were unnoticed in the wastes they will complete in these wastes their cycle and the RPW will continue to breed. These two assertions are wrong because females will not lay their eggs in drying or dead tissue and larvae will not survive in such tissues. For eggs and first larvae instars to survive, they must be placed in living tissue that the RPW females reach by drilling oviposition holes. The larvae, contrary to what is still often assumed, are not xylophagous, they don't ingest the "wood" of the palms; they just chew the fibres and suck the liquid extracted from them. Thus, they can survive outside living tissues.

The risk in the wastes handling is not constituted by the eggs or the larvae but by the adults and the cocoons, that are not too difficult to locate and then eradicate.

Therefore, the handling of the wastes, even for heavily infested palms, is very simple and can be perfectly implemented by a farmer with simple tools or eventually a chain saw (Ferry and Aldobai, in press). For the tall Phoenix canariensis that are too heavily infested to be sanitized, it is sufficient to cut the top part of the trunk. The remaining trunk can stay in situ to be handled later like a usual dead trunk. When no intervention is operated on an infested Phoenix canariensis, it will die and when all its leaves become dry, it will no more be a RPW breeding spot.

Unfortunately, because of the general misconception previously described, very huge efforts and a lot of time and money have been dedicated to eradicate the whole palms following complex protocols: wrapping the palm, felling the palm, transporting the whole palm, burning the whole palm or burying it or shredding it in huge and very costly machine.

A lot of money and efforts could have been saved if instead of eradicating the whole infested palms, only the infested parts would have considered as the parts to be treated. These reduced parts of the infested palms could have been perfectly handled on the spot with simple tools and methods. In addition, such handling presents the great advantage of not taking the risk to spread the weevil during a transport.

In the Valencia region in Spain, 25 million Euros were spent from 2004 to 2009 in support of the programme to eradicate the weevil. Most of this amount was used to eradicate the whole infested palms. Very little money was available for the other indispensable tasks to succeed the eradication of the pest. Consequently, the RPW continued to spread in the whole region, and, as year after year the budget to dedicate to the eradication of the infested palms continued to increase, the regional plant protection authority decided brutally to abandon the fight in 2009.

Compared with what has been done till now in most of the countries, saving money on the management of the infested palms is easy and will allow to dedicate money, means and efforts to other essential fields.

Lesson 6: The efficient management and monitoring of the RPW eradication programmes request the assistance of a GIS at the local, regional and national level.

It is very surprising to observe that, in nearly all the infested countries, data and maps on the situation and on its evolution, year after year, at the local as well as the regional and national levels, are not available or are poorly documented.

Without this information, continuously updated, it is not possible to know if and where the activities of the program are or are not implemented as planned and where and why they allow or not to obtain the targeted RPW decline. Without this information, it is very difficult to manage efficiently a RPW control programme at the local, regional and national levels

Without this tool, it is not easy to dispose of an efficient early warning system which is essential to obtain the rapid implementation of contingency measures.

Moises Fajardo who was in charge of the eradication programme in the Canary Islands has assured that "RPW eradication in the Canary Islands would have been impossible without GIS” (Fajardo, 2017b).

\section{Conclusions}

Important lessons can be drawn from the analysis of the present situation and of the RPW control programmes implemented in the world for the last 30 years. Although the situation is very serious in all the infested countries, it is clear that, on many issues, the programmes can and should be modified rapidly. If it is not done, the palms hecatomb will continue. In the cities, the palms patrimony will disappear completely in the short term. In the oasis, the socio-economic and environmental consequences of the RPW expansion will become really dramatic.

The programmes must be modified, but the objective must also be clearly established. On the basis of the three scenarios corresponding to the evolution of the situation for the last thirty years presented in this paper, the objective must be clearly to obtain the rapid decline of the pest in pilot areas. From these initial zones, this strategy will be progressively implemented to larger and larger areas.

As the infestation concerns now very wide areas, the participation of the palms owners and their organizations is 
indispensable. Till now, very little efforts and methods have been dedicated to obtain the participation of these essential actors, because it was considered that it was useless and because no socio-economists with expertise in participatory approach and farming systems analysis were involved in the RPW control programmes. The problem of the RPW was only considered from the technical point of view. Which technique, which product, which equipment, which regulation? The socio-economic dimension of the problem was not considered, as demonstrated by the nearly total lack of data in this field. On the human and social issue, the first concerned actors, the palms owners and their organization were barely consulted and involved in the conception and implementation of the programmes.

In date producing countries, the farming systems are diverse. To simplify the situation, they can be divided into few groups: the traditional farming systems and the "modern" large great plantations. Regarding the traditional farming systems themselves, they can be of quite different types: the farms in which date production constitutes an important source of income for the palm owners and the farms that have mainly a recreational and societal vocation for their owners.

The solutions to propose and to discuss with the farmers will have to take into consideration these different farming systems. Nevertheless, as the RPW ignores these differences (except that they can have agronomic consequences that will interfere with its behavior), the success of its control in the large farms depends on its success in the traditional farms.

\section{الملخص \\ فيري، ميشيل. 2019. الحالة العالمية والاروس الرئيسة لثلاثين سنة من الكفاح إزاء سوسة النخيل الحمراء. مجلة وقاية النبات العربية، \\ .118-109:(2)37}

لقد أدّت حركة الاستير اد الخارجي و التداول الداخلي لأشجار/فسائل النخيل المصابة إلى إدخال وانتشار سوسة النخيل الحمر اء في كامل بلدان منطقة الشرق الأدنى وشمال إفريقيا (باستثناء الجز ائر والسودان) وكذلك في دول الساحل الثمالي لحوض البحر الأبيض المتوسط؛ وقد جرت هذه الحركة والتداول بشكلٍ رسمي.

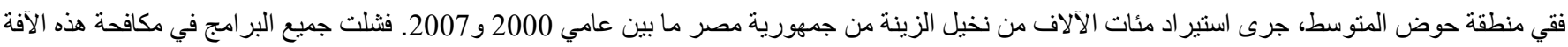
ضمن جميع الدول الموبوءة بها، ويرزح الوضع الحالي تحت وطأة خطرِ كبير بآتاره الاجتماعية_الاقتصادية في الدول المنتجة للتمور، فضلاً عن تشويهٍ كبير للمنظر الطبيعي في تللك الأماكن التي يزرع فيها النخيل لأغر اض الزينة. و لاقتر اح حلولٍ سليمةٍ ومستدامةٍ لمكافحة هذه الآفة الخطرة، فإنّه لابدّ من استخلاص العبر سواءً من

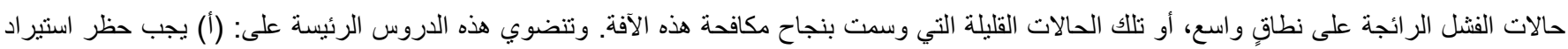

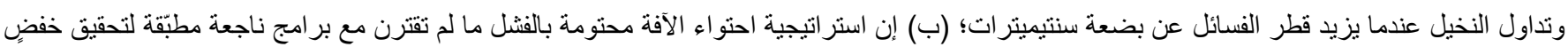

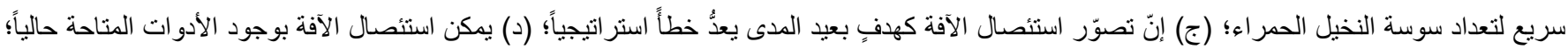
(ه) يعدّ النموذج القائل بأنّ استثـصال الآفة يعني الاستئصال التلقائي لأشجار النخيل المصابة أمر اً خاطئً؛ (و) ليست المشكلة الرئيسية مسألثة تقنية و إنّما اجتماعيةاقتصادية وتنظيمة؛ (ز) يجب اجتر اح دراساتٍ اجتماعية_اقتصادية على نحٍِ عاجل، كما يتوجب تطبيق النهج التشاركي لدمج مالكي النخيل ومنظماتهم على نطاقٍ واسع ضمن بر امج الخفض السريع واستئصسال سوسة النخيل الحمر اء.

كلمات مفتاحية: Phoenix canariensis ‘Phoenix dactylifera Rhynchophorus ferrugineus، سوق نخيل الزينة، استنئصسال، خفض سريع، احتواء، منطقة الشرق الأنى وشمال إفريقيا، منطقة حوض المتو سط، اجتماعية_اقتصادية، لائحة صحيّة نباتية، إجر اءات صحيّة، إدارة، نهج نشاركي، المكافحة

\section{References}

Abdedaiem, S., N. Nasr and M. Ferry (In press). Études et approches socio-économiques pour l'implication des agriculteurs dans le programme de lutte contre le CRP. Proceedings of the "Scientific Consultation and HighLevel Meeting on Red Palm Weevil Management", organized by FAO and CIHEAM, Italy, 29-31 March, 2017, Rome, Italy FAO.

Abraham, V.A., M. Al-Shuaibi, J.R. Faleiro, R.A. Abouzubairah and P.S.P.V. Vidyasagar. 1998. An integrated approach for the management of red palm weevil Rhynchophorus ferrugineus Oliv.- A key pest of date palm in the Middle East. Journal of Agricultural and Marine Sciences [JAMS], 3: 77-83. https://doi.org/10.24200/jams.vol3iss1pp77-83
Aldryhim, Y. and A. Khalil. 2003. Effect of humidity and soil type on survival and behavior of red palm weevil Rhynchophorus ferrugineus (Oliv.) adults. Journal of Agricultural and Marine Sciences [JAMS], 8: 47-49 https://dx.doi.org/10.24200/jams.vol8iss1pp47-49

CE, 2017 Commission Implementing Directive (EU) 2017/1279 of 14 July 2017 amending Annexes I to V to Council Directive 2000/29/EC on protective measures against the introduction into the Community of organisms harmful to plants or plant products and against their spread within the Community

Cox, M.L. 1993. Red palm weevil, Rhynchophorus ferrugineus in Egypt. FAO Plant Protection Bulletin, 41: $30-31$. 
Fajardo, M. (in press). 2017a. Using GIS in RPW eradication. Presented at the "Scientific Consultation and High-Level Meeting on Red Palm Weevil Management", organized by FAO and CIHEAM, Italy, 29-31 March, 2017, Rome, Italy

Fajardo, M. (in press). The Canary Islands success story in eradicating red palm weevil. Proceedings of the "Scientific Consultation and High-Level Meeting on Red Palm Weevil Management", organized by FAO and CIHEAM, Italy, 29-31 March, 2017, Rome, Italy FAO.

Faleiro, J.R., J. Ashok Kumar and P.A. Rangnekar. 2002. Spatial distribution of red palm weevil Rhynchophorus ferrugineus Oliv. (Coleoptera: Cuculionidae) in coconut plantations. Crop Protection, 21: 171-176. https://doi.org/10.1016/s0261-2194(01)00083-7

Faleiro, J.R. 2006. A review of the issues and management of the red palm weevil Rhynchophorus ferrugineus (Coleoptera: Rhynchophoridae) in coconut and date palm during the last one hundred years. International Journal of Tropical Insect Science 26, 135-154. https://doi.org/10.1079/IJT2006113

Faleiro, J.R., M. Ferry and N. Nasr. 2017. Rapport de mission en Mauritanie du 18 au 23 juin 2017sur le projet d'éradication du CRP. Bilan et établissement de la feuille de route. $7 \mathrm{pp}$.

Ferry, M. 1996. La crise du secteur phoenicicole dans les pays méditerranéens. Quelles recherches pour y répondre? In: Le palmier dattier dans l'agriculture d'oasis des pays méditerranéens Journées Internationales d'Elche sur le Palmier Dattier dans L'Agriculture d'Oasis des Pays Méditerranéens. M. Ferry and D. Greiner (ed.). 25-27 Apr 1995, Elche (Spain). Options Méditerranéennes : Série A. Séminaires Méditerranéens, 28: 129-156.

Ferry, M. 2012a. Evaluation de la situation au Maroc, en Algérie et en Tunisie et élaboration d'un plan de travail. Rapport de mission au Maroc, en Algérie et en Tunisie du 25/3/12 au 18/4/12. FAO, 85 pp.

Ferry, M. 2012b. Training of trainers from Mauritania, Morocco, Algeria, Tunisia, Libya. Rapport de Mission en Tunisie du 26/5 au 4/6/2012. FAO, 35 pp.

Ferry, M. 2012c. Assessment of the situation and elaboration of an action Plan and of the protocols for each of the components of the eradication strategy. Mission de Consultation en Tunisie du 10/12 au 14/12/2012. FAO, 36 pp.

Ferry, M. 2012d. Report on the study tour in Oman. September 14-21, 2012. FAO, 19 pp.

Ferry, M. 2014. Assessment of the situation on the RPW and on the activities to control this pest in Gaza and Jericho. Recommendations. Report of consultancy in Gaza and Jericho. 25 to 31 of January 2014. FAO. 23 pp.

Ferry, M. (in press). Recent advances in insecticide treatments against red palm weevil. Proceedings of the "Scientific Consultation and High-Level Meeting on Red Palm Weevil Management", organized by FAO and CIHEAM, Italy, 29-31 March, 2017, Rome, Italy FAO.
Ferry, M. and S. Aldobai. (in press). National components of the strategy for the management of red palm weevil. Proceedings of the "Scientific Consultation and HighLevel Meeting on Red Palm Weevil Management", organized by FAO and CIHEAM, Italy, 29-31 March, 2017, Rome, Italy FAO

Ferry, M. and S. Gómez. 2002. The red palm weevil in the Mediterranean area. Palms, 46: 172-178.

Ferry, M. and S. Gómez. 2007a. Recommendations for the control of the red palm weevil. International workshop on the integrated strategy to control the RPW. Elche, 23-24/4/2007. Ayto. Elche. 76 pp.

Ferry, M. and S. Gómez. 2007b. El picudo rojo de la palmera datilera: gravedad de la plaga en España y necesidad de un cambio radical y urgente de estrategia en la lucha. Phytoma, $186: 42-46$.

Ferry, M. and S. Gómez. 2008. Une nouvelle stratégie contre le charançon rouge des palmiers. Phytoma, $620: 24-28$.

Ferry, M. and S. Gómez. 2013. La lucha contra el picudo rojo: lecciones de un fracaso. La cultura del arbol, 67: 25-37.

Ferry, M., J.R. Faleiro, K. Cressman and S. Al-Dobai. 2016. Mission Report on Red Palm Weevil Management in the Kingdom of Saudi Arabia from 07 to 15 May 2016. FAO, 34 pp.

Ferry, M., S. Aldobai and H. Elkakhy (in press). The state of art of the control of the red palm weevil. Proceedings of the Sixth International Date Palm Conference, 1921 March 2018, Abu Dhabi. Ministry of Presidential Affairs. UAE.

Hoddle, M.S., C.D. Hoddle, J.R. Faleiro, H.A.F. ElShafie, D.R. Jeske and A.A Sallam. 2015. How far can the red palm weevil (Coleoptera: Curculionidae) Fly?: Computerized Flight Mill Studies With FieldCaptured Weevils. Journal of Economic Entomology, 108: 2599-2609.

https://doi.org/10.1093/jee/tov240

Kean, J.M., D.M. Suckling, N.T. Sullivan, P.C. Tobin, L.D. Stringer, G.R. Smith, B. Kimber, D.C. Lee, R. Flores Vargas, J. Fletcher, F. Macbeth, D.G. McCullough, and D.A. Herms et al. 2019. Global eradication and response database. http://b3.net.nz/gerda (accessed 31 January 2019).

Massoud M.A., A.A. Sallam, J.R. Faleiro and S. AlAbdan. 2012. Geographic information system-based study to ascertain the spatial and temporal spread of red palm weevil Rhynchophorus ferrugineus (Coleoptera: Curculionidae) in date plantations. International Journal of Tropical Insect Science, 32: 108-115. https://doi.org/10.1017/s174275841200015x

Monzer, M.A. and A.S. Hesham. 2009. Desiccation intolerance of the red palm weevil, Rhynchophorus ferrugineus (oliv) adults in relation to their cuticular hydrocarbons. Egyptian Academic Journal of Biological Sciences (A. Entomology), 2: 47-53. https://doi.org/10.21608/eajbsa.2009.15452 